им. В. В. Виноградова. - [4-е изд., дополненное]. - Москва : ООО «А ТЕМП», 2006. - 944 с. 6. Селевко Г. К. Энциклопедия образовательных технологий: В 2 т. - Т. 1. - Москва : НИИ школьных технологий, 2006. - 816 с. 7. Синергетика і освіта: [монографія] / за ред. В. Г. Кременя. - Київ : Інститут обдарованої дитини, 2014. - 348 с. 8. Сластенин В. А. Введение в педагогическую аксиологию: [учеб. пособ. для студентов педагогических вузов] / $\quad$ В. А. Сластенин, Г. И. Чижакова. - Москва : Академия, 2003. - 192 с. 9. Коджаспирова Г. М. Словарь по педагогике / Г. М. Коджаспирова, А. Ю. Коджаспиров. Москва : ИКЦ «МарТ», 2005. - 448 с. 10. Философский энциклопедический словарь / Н. М. Ланда [и др.]. - Изд-во : Москва: Советская энциклопедия, 1983. - 840 с.

УДК 37.011.3-051:78

Володимир Костюков

\title{
ДІАГНОСТИКА ФОРМУВАННЯ ПЕДАГОГІЧНО-АРТИСТИЧНИХ УМІНЬ МАЙБУТНІХ УЧИТЕЛІВ МУЗИКИ
}

Костюков В. В. Діагностика формування педагогічно-артистичних умінь майбутніх учителів музики.

У статті розглянуто питання формування педагогічно-артистичних умінь майбутніх учителів музики в процесі фахового навчання. Виокремлено діагностувальний етап експериментальної роботи, який полягає в констатації вмінь використовувати можливості голосу, особистісної готовності до вияву артистичних здібностей, особистісного налаштування на вокальну роботу зі школярами. У результаті експериментальної роботи розроблено три рівні сформованості педагогічно-артистичних умінь студентів, а саме: високий, середній, низький. У результаті порівняння кількісної характеристики рівнів сформованості мотиваційно-пізнавального компонента на початковому етапі діагностики педагогічно-артистичних умінь з'ясовано, що серед майбутніх учителів музики виявлена переважна більшість студентів із низьким і середнім рівнями мотивації до оволодіння педагогічно-артистичними вміннями як основою педагогічної майстерності.

Ключові слова: педагогічно-артистичні вміння, діагностика, констатувальний експеримент, майбутній учитель музики.

Костюков В. В. Диагностика формирования педагогическо-артистических умений будущих учителей музыки.

В статье рассматриваются вопросы формирования педагогическо-артистических умений будущих учителей музыки в процессе профессионального обучения. Выделен диагностический этап экспериментальной работы, который заключался в констатации умений использовать возможности голоса, личностной готовности к проявлению артистических способностей, личностной настройки на вокальную работу со школьниками.

В результате экспериментальной работы разработаны три уровня сформированности педагогическо-артистических умений студентов, а именно: высокий, средний, низкий. В результате осуществления сравнения количественной характеристики уровней сформированности мотивационно-познавательного компонента на начальном этапе диагностики педагогическо-артистических умений установлено, что среди будущих учителей музыки обнаружено подавляющее большинство студентов с низким и средним уровнями мотивации к овладению педагогическо-артистическими умениями как основой педагогического мастерства. 
Ключевые слова: педагогическо-артистические умения, диагностика, констатирующий эксперимент, будущий учитель музыки.

Kostjukov V. V. Diagnostics of pedagogical and artistic skills formation of future music teachers.

This article deals with the formation of pedagogical and artistic skills of the future teachers of music in the process of professional skills training. The diagnostic stage of experimental work which consisted of abilities to use possibilities of a voice, personal readiness for demonstration of artistic abilities, personal readiness for vocal work with school students was given. As a result of the experimental work three formation levels of pedagogical and artistic skills of students were developed. They are high, medium and low. As a result of the quantitative characteristic comparison of the formation levels of a motivational and cognitive component at the initial stage of diagnostics of pedagogical and artistic skills it was found that among future music teachers there were a lot of students with low and average motivation levels to mastering pedagogical and artistic skills as a basis of pedagogical excellence.

Key words: pedagogical and artistic skills, diagnostics, ascertaining experiment, the future teacher of music.

Праця вчителя - одна $з$ небагатьох, яку можна назвати вічною. Ніхто і ніщо не зможуть замінити вчителя, його творчу особистість зі своїм неповторним іміджем. Учитель $\epsilon$ людиною, у якої немає іншого морального вибору, окрім чистоти, щирості, відкритості і прямоти, йому притаманні вимоглива любов до дітей, доброта, щирість у судженнях і діях, інтелігентність, освіченість, вихованість, людяність, почуття гідності, стійкості, здатність гідно триматися у важких ситуаціях. Для цього майбутньому вчителю необхідно володіти цілим комплексом засобів, серед яких виокремлюється артистизм як важлива професійна якість, що дозволяє здійснювати професійний вплив на цінності учнів, їх стосунки, сприяти творчому зростанню. Ідея педагогічного артистизму у творчості вчителя розроблялася у працях Ю. Азарова, П. Блонського, А. Єршової, І. Зязюна, . Кривоноса, Г. Лозанова, А. Макаренка, Н. Тарасевич та ін.

Мета статmі- розроблення діагностуальної методики та визначення рівнів сформованості педагогічно-артистичних умінь майбутніх учителів музики. Діагностувальний експеримент був спрямований на діагностику сформованості педагогічно-артистичних умінь майбутніх учителів музики та проходив у кілька етапів. Кожен етап констатувального експерименту було підпорядковано певній меті, визначеним дослідницьким завданням.

Констатувальний етап експерименту передбачав діагностику вміння використовувати можливості голосу, особистісної готовності до вияву артистичних здібностей, особистісного налаштування на вокальну роботу зі школярами.

Для розв’язання визначених завдань застосували авторську модифіковану методику, розроблену на основі тестів А. Кареліна [1, с. 112]. Результати аналізу отриманих даних дозволяють констатувати, що високу мотиваційну спрямованість до здобуття педагогічноартистичних умінь серед опитуваних було виявлено у $10 \%$. Студенти середнього рівня (55,5%) обмежуються лише виконанням навчальних вимог, про що свідчить погодження 3 такими твердженнями, як: «більшість студентів повинні думати не про майбутню фахову діяльність, а про навчання» або «для мене важливим постає не саме виконання вокального твору, а отримана оцінка як кінцевий результат» тощо. Третина досліджуваних - 18,5 \% відверто демонструють пасивне ставлення до процесу набуття вокальних умінь, оскільки 
вважають, що якість виступу від них не залежить, про що свідчать такі відповіді: «успіх виконання вокального твору залежить від випадку, а не від рівня готовності співака», «всі мої невдачі під час прилюдного співу вокального твору через те, що я недостатньо обдарована людина». Студенти цієї групи відрізняються виявом нерегулярності самостійної підготовки, оскільки невпевнені у власних навчальних можливостях. Побоювання й невпевненість через свою неорганізованість у навчальній діяльності продемонстрували 37 \% студентів середнього рівня, які погодились із твердженнями: «викладачі вважають мене несамостійним», «я забуваю про гігієну голосу і можу співати довгий час голосно не контролюючи вокальне дихання та співацьку поставу» тощо. Натомість, досить вагомий відсоток (34,5\%) становить група студентів із низьким рівнем мотиваційної спрямованості до здобуття педагогічно-артистичних умінь, які у своій навчальній вокальній діяльності взагалі уникають будь-якої можливості виконавської діяльності перед будь-якою аудиторією слухачів, оскільки вважають себе неталановитими, користуються помилковими уявленнями про співацький процес.

Наявність особистісної готовності майбутніх учителів музики до вияву артистичних здібностей у процесі вокально-методичної підготовки визначалась за допомогою тесту, розробленого на основі модифікованої методики В. Лівшиця [2, с. 102-104].

У результаті оброблення результатів показника, з’ясувалось, що студентів із високим рівнем було виявлено лише 10 \%. Студенти із середнім рівнем пізнавального інтересу мають потребу в набутті вміння висловлювати своє розуміння вокального твору за допомогою міміки та жестів, спираючись на відчуття краси, властиве їх артистичній натурі. Респонденти свою навчальну діяльність будують на раціональному співвідношенні. Представники цього рівня склали переважну більшість - 56,9%. Низький рівень особистісної готовності до вияву артистичних здібностей продемонстрували $33,1 \%$ студентів. Такі студенти під час виконання вокального твору більше спираються на свій емоційний настрій, зосереджуючись на навчальних проблемах, не виявляють потреби в пошуку способів зовнішнього висловлення свого ставлення до вокального твору, тому вони дали позитивну відповідь на такі запитання, як «Оволодіваєте навичками співу тільки для того, щоб закінчити ВНЗ?», «Під час концертного виконання вокального твору Ви відраховуєте паузи, не відчуваючи плинності музики?», або негативну відповідь на такі питання, як «Чи можете відобразити сум на обличчі під час співу, коли у Вас гарний настрій?».

За зведеними результатами етапу констатувального експерименту можна виявити рівні сформованості педагогічно-артистичних умінь майбутніх учителів музики.

Високий рівень сформованості мотиваційно-пізнавального компонента характеризується: виявом активної цілеспрямованості щодо оволодіння вокальновиконавською діяльністю; позитивним ставленням до виконання вокальних творів; стійкою особистою готовністю до розвитку власного співацького голосу; наявністю пізнавального інтересу до вивчення дисциплін вокально-методичного циклу, потребою в розвитку артистичних здібностей. На констатувальному етапі педагогічного діагностування до високого рівня було віднесено 7,8 \% досліджуваних.

Середній рівень сформованості мотиваційно-пізнавального компонента визначають: позитивне ставлення до виконання вокальних творів через несистематичний характер самостійної діяльності, тому студенти цього рівня не відчувають упевненості у своїх можливостях яскраво представити вокальний твір перед слухацькою аудиторією; їм властива стриманість у висловленні під час співу художньо-образної змістовності вокального твору. Такі студенти усвідомлюють важливість розвитку артистичних умінь у процесі оволодіння 
вокальними прийомами та вокально-технічними вміннями та навичками, однак не здатні використовувати комплексно набуте. Респондентів цього рівня налічується 42,1%.

Низький рівень мотиваційно-пізнавального компонента характеризує пасивним ставленням до вокально-виконавської діяльності, заниженою самооцінкою щодо природних даних співацького голосу, а також негативним ставленням до глибинного аналізу змістовності вокального твору. Такі студенти демонструють слабкий інтерес до навчальної роботи над мімікою, жестами під час співу, що виявляється у стриманості емоційнопочуттєвої сфери та призводить до скутості голосового апарату. До низького рівня мотиваційно-пізнавального компонента віднесено 50 \% респондентів.

Подальша діагностувальна робота мала на меті виявити у студентів уміння творчого використання набутих знань і вмінь у процесі навчальної роботи з музичним матеріалом, літературним текстом вокального твору, самовираженні у процесі виконавської творчості. Для з'ясування особливостей вияву показників виконавсько-творчого компонента були розроблені спеціальні контрольні зрізи, зміст яких передбачав виконання майбутніми вчителями музики серії експериментальних завдань, заповнення шкал самооцінки, тестів діяльності.

Діагностика рівня сформованості вміння студентів вільно оперувати музичним матеріалом здійснювалася за допомогою контрольного зрізу, що передбачав як практичну роботу з музичним матеріалом, так і проведення анкетування. Контрольний зріз передбачав забезпечення студентів нотним матеріалом незнайомого вокального твору, за яким необхідно було здійснити музично-теоретичний аналіз. Під час створення таблиці проаналізовано відповіді студентів на запитання анкети щодо навичок, якими вони володіють на достатньому рівні. У професійній діяльності вчителя музичного мистецтва важливим аспектом є реалізація таких функцій, як навчальна, діагностична, мотиваційна, розвивальна, контрольна, регулювальна, прогностична.

Як свідчать результати дослідження, опитані майбутні вчителі музики володіють на достатньому рівні лише найпростішими і найелементарнішими навичками: сольфеджування мелодійної лінії - 100 \%, відтворення ритмічного малюнку вокального твору - 90 \%, гра на музичному інструменті мелодійної лінії - $100 \%$, музично-теоретичний аналіз вокального твору - $65 \%$, спів вокального твору - $80 \%$, висловлення композиторського задуму під час співу - $45 \%$. Проте залишається безліч навичок, які студенти не прагнуть здобувати в навчальній діяльності. Проаналізувавши результати, можна виокремити навички, якими студенти не володіють: читання 3 листа - 5\%, підбір костюму для виступу - $20 \%$, використання сонористичних прийомів під час співу - 2 \%, володіння сценічними жестами відповідно до стилю і жанру вокального твору - 4 \%, здійснення презентації вокального твору - $15 \%$, використання наочності для створення сценічного образу - 5 \%. Використовуючи ці навички, майбутні вчителі музики могли б яскраво виявити себе під час педагогічної діяльності.

У результаті оброблення експериментальних даних виявилося, що лише 11,8 \% майбутніх учителів музики дійсно володіють умінням вільно оперувати музичним матеріалом. Студенти 3 високим рівнем уміння оперувати музичним матеріалом мають потребу у здійсненні творчої роботи з ним, спрямованої на пошук нових способів яскравого виконання. Респондентів середнього рівня відрізняє інша мотивація до процесу навчальної роботи над вокальним твором, а саме прагнення виконати добре навчальне завдання. Однак їх навчальні дії не спрямовані на творчу роботу з музичним матеріалом, не здійснювався пошук нового вирішення навчального завдання. Представники цього рівня склали переважну 
більшість - 65 \%. До низького рівня було віднесено 23,2 \% респондентів, які виявляють низький інтерес до процесу творчої навчальної роботи над музичним твором, а тому вони фрагментарно виконували навчальне завдання, застосовуючи набуті знання та вміння.

Діагностичні зрізи рівнів сформованості вміння студентів творчо працювати над літературним текстом вокального твору були проведені в навчальних умовах - під час складання заліку з дисципліни «Постановка голосу», у процесі виконання студентами вокальних творів за навчальною програмою. Експертам було запропоновано оцінити ступінь здатності кожного студента до творчої роботи над літературним текстом вокального твору, що було здійснено самостійно у процесі підготовки до заліку. Оцінювання виступу студентів здійснювалось експертами за параметрами: яскраве представлення виконання вокального твору; чітка, ясна дикція під час співу; усвідомлена вимова слів; виділення головних слів під час співу; ступінь зображальності звучання головних слів вокального твору; динаміка розвитку композиційної лінії твору за допомогою донесення слухачу літературного тексту вокального твору; відчуття цілісності відтворення художньо-образного змісту; збереження характеру виконання твору після закінчення співу. До високого рівня було віднесено 7 \% студентів, які під час співу вокального твору продемонстрували свідомий погляд, звертаючись до уявного персонажу, чітку дикцію, емоційну наповненість кожного слова літературного тексту. До середнього рівня було віднесено 64 \% студентів, які під час співу виділяли головні слова літературного тексту в кульмінаційних фрагментах вокального твору, зрозуміло вимовляли слова, проте ці слова оцінювались експертами як «пусті», неусвідомлені самим студентом. Студенти, які виявили низький рівень (29\%), під час виконання вокального твору головну увагу звертали тільки на вчасний вдих, правильне виконання мелодійної лінії, витримку пауз, фермат. При цьому, вимова літературного тексту вокального твору була нечіткою, деякі слова були поза увагою студента.

\section{Література}

1. Карелин А. А. Психологические тесты в 2 т. / А. А. Карелин. - Москва : Гуманит. изд. центр «Владос», 2002. - Т. 1. - 312 с. 2. Лившиц В. Ю. Современная энциклопедия психологических тестов : 300 тестов / В. Ю. Лившиц. - Донецк : ООО ПКФ «БАО», 2005. 384 с. 3. Майковская Л. С. Артистизм учителя музыки: [учеб. пособие] / Л. С. Майковская. [2 изд. доп.]. - Москва : Моск. гос. ун-т культуры и искусств, 2005. - 74 с.

УДК 378.147:37.0011

Дар'я Кудренко

\section{РОЛЬ ДИФЕРЕНЦЙОВАНОГО НАВЧАННЯ У ФАХОВІЙ ПІДГОТОВЦІ СТУДЕНТІВ ХУДОЖНЬО-ГРАФІЧНИХ ФАКУЛЬТЕТІВ}

Кудренко Д. О. Роль диференційованого навчання у фаховій підготовці студентів художньо-графічних факультетів.

У статті проаналізовано роль та місце диференційованого підходу у фаховій підготовці майбутніх учителів образотворчого мистецтва, висвітлюється специфіка зовнішньої та внутрішньої диференціації навчального процесу; указано на важливість застосування внутрішньої диференціації для розкриття пізнавальних можливостей, вияву художніх здібностей студентів мистецьких спеціальностей.

Ключові слова: диференційоване навчання, внутрішня диференціація, студенти факультету мистецтв, навчальна діяльність, художній образ, художньо-творчі здібності. 